
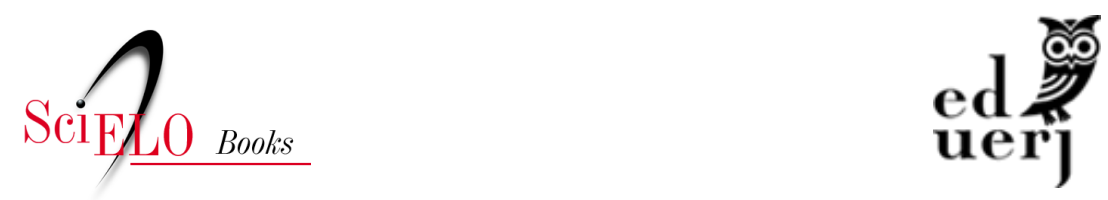

\title{
Conclusão - Considerações normativas sobre o congresso remoto
}

\author{
San Romanelli Assumpção
}

\section{SciELO Books / SciELO Livros / SciELO Libros}

ASSUMPÇÃO, S. R. Considerações normativas sobre o congresso remoto. In.: SANTOS, F., ed. Congresso remoto: a experiência legislativa brasileira em tempos de pandemia [online]. Rio de Janeiro, 2021, pp. 129-138. Sociedade e política collection. ISBN: 978-65-88808-12-2.

https://doi.org/10.7476/9786588808122.0010.

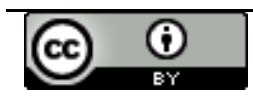

All the contents of this work, except where otherwise noted, is licensed under a Creative Commons Attribution 4.0 International license.

Todo o conteúdo deste trabalho, exceto quando houver ressalva, é publicado sob a licença Creative Commons Atribição 4.0.

Todo el contenido de esta obra, excepto donde se indique lo contrario, está bajo licencia de la licencia Creative Commons Reconocimento 4.0. 


\section{CONCLUSÃo \\ CONSIDERAÇÕES NORMATIVAS SOBRE O CONGRESSO REMOTO}

San Romanelli Assumpção

\section{Introdução}

No capítulo 7, João Feres Júnior discorreu sobre o tratamento dispensado pelo pensamento político e pelas instituiçóes políticas ocidentais à questão da crise, refletindo sobre conceitos e relações. Neste capítulo conclusivo, propomos refletir sobre esses mesmos conceitos e relações, mas em uma chave normativa aplicada ao presente brasileiro.

São muitas as perspectivas sobre a realidade objetiva da democracia no Brasil - dentro de perspectivas científicas sobre a democracia - bem como são muitas as perspectivas teórico-normativas sobre como os movimentos da democracia podem ser avaliados na experiência recente do país. Dentro de toda essa pluralidade, podemos, provisoriamente, estabelecer três consensos mínimos significativos, ainda que pouco ambiciosos intelectualmente:

1. As muitas crises da pandemia são de fato crises (segundo as teorizações discutidas por Feres Jr.);

2. As interações políticas, entre múltiplos atores distribuídos em três poderes e nos diferentes níveis da federação, 
não resultaram em interrupção do regime democrático no país;

3. A rápida reação do Congresso - expressa no Congresso Remoto - foi e é parte constitutiva fundamental dessa não interrupção.

Como estes três pontos podem ser avaliados dentro de uma moralidade política democrática e liberal? O que isso diz normativamente sobre nossa democracia? Como isso pode ser explorado politicamente como potencialidade positiva?

\section{A crise é social}

As muitas crises desencadeadas pela pandemia são, inegavelmente, crises cujos efeitos se encadeiam e desencadeiam em amplitude e profundidade generalizante:

1. o surgimento de uma nova doença, cuja cura e vacina eram desconhecidas até muito recentemente, sobrecarrega os sistemas públicos e privados de saúde de modo que a única maneira conhecida de conter a escalada do número de mortes é o isolamento físico;

2. o isolamento físico impacta o mercado ao paralisar atividades, extinguir empregos, levar empresas à falência e atingir vastas parcelas da população;

3. esses impactos econômicos de grande escala exigem respostas estatais custosas monetariamente e em termos de recursos humanos, onerosas institucionalmente nas mais diversas esferas burocráticas e políticas, e ameaçadoras da capacidade estatal de respeitar e efetivar direitos nas quatro dimensões principais da cidadania (civil, política, socioeconômica e de segurança pessoal); 
4. a integração e movimentos de capitais e pessoas próprios do mundo globalizado contemporâneo impedem que qualquer Estado consiga lidar com essas crises encadeadas de modo meramente local, isto é, impedindo movimentos transnacionais de capitais e pessoas. Muito mais do que isso poderia ser dito sobre crises encadeadas, no entanto, para construção de nossa argumentação normativa, fiquemos apenas com os elementos aqui expostos, sobre os quais é possível relativo acordo intelectual entre pessoas de perspectivas ontológicas, epistemológicas e normativas distintas.

Esses quatro elementos simples e cientificamente pouco pretensiosos mostram que o conceito de crise é corretamente aplicado ao contexto pandêmico e que, como as crises mais graves, esta é uma crise que perpassa as mais diversas dimensões da vida social, de modo que os aspectos médicos da crise, por mais cruciais que sejam, são apenas uma parte dela. Antes que os leitores se assustem com essa afirmação, lembramos que o número de pessoas que passarão fome e morrerão de fome (neste e nos próximos anos) em decorrência da pandemia ultrapassará o número de mortos pela Covid-19. Citando um dos pais da epidemiologia social, Rudolf Virchow, "uma epidemia é um fenômeno social que possui alguns aspectos médicos" (Virchow apud Lévy, 2020) e, como não poderia ser diferente, uma pandemia, também o é (Lévy, 2020).

A pandemia é social por diversas razões: (i) por expressar uma ontologia a respeito da relação entre a dimensão médico-sanitária e as demais dimensões da realidade social na qual a interdependência é central; (ii) por expressar uma perspectiva em que o social é parte tão importante quanto aquilo que é estritamente médico, tanto em relação ao entendimento científico da pandemia quanto em relação ao modo como a normatividade deve enquadrar a pandemia enquanto problema de moralidade política; (iii) por colocar 
dentro do que é social todas as dimensões da vida coletiva humana, isto é, as dimensões médica, sanitária, individual, comunitária nas mais diversas comunidades, econômica, estatal, política, civil, cultural, tradicional, religiosa etc.; (iv) por compreender o social de maneira que, analiticamente, se possa conceber o que é sanitário, econômico, estatal e político como dimensões distintas o suficiente para serem entendidas como relacionais; (v) por compreender a pandemia como algo que, por ser social, pode ser impactado por meio de construçôes sociais; (vi) por colocar a pandemia como algo socialmente construído e, portanto, passível de ação especificamente estatal e política.

\section{A pandemia é estatal e política}

A proposição de que a pandemia é estatal é, à primeira vista, contraintuitiva, afinal, como uma pandemia, cuja especificidade é seu caráter mundial/global, que transcende fronteiras, pode ser estatal? Parece haver uma contradição em termos aqui, afinal, faz parte da definição moderna de Estado a ideia de que este é detentor de autoridade soberana inseparável de sua dimensão territorial local. Um Estado é detentor de soberania em suas faces interna (voltada para seus cidadãos ou súditos, dentro de seu território) e externa (voltada para os demais Estados soberanos). De acordo com essas duas faces territorialmente delimitadas, um Estado exerce a soberania por meio dos monopólios de uso legítimo da violência, de promulgação de leis, de emissão de moeda, de cobrança de impostos e de negociação de acordos internacionais e tomada de empréstimos em nome do povo que habita seu território. Pensando nisso tudo, nada menos transnacional do que um Estado e suas soberanias e monopólios territorialmente definidos. E nada mais transnacional do que uma pandemia e suas múltiplas crises inescapavelmente encadeadas por mecanismos que envolvem o caráter global da circulação 
de pessoas, capitais e vírus no século XXI. Sendo assim, o que de fato queremos dizer quando afirmamos que a pandemia é estatal?

A pandemia é teorizável como estatal, porque as formas pelas quais as múltiplas crises por ela desencadeadas impactam a vida das pessoas e das comunidades são indissociáveis das formas pelas quais o Estado, no exercício das suas soberanias e monopólios, ativamente lida com essas crises (como estão fazendo Estados como os do Reino Unido, da Alemanha e da China) ou ativamente tenta negar as diversas dimensões da crise pandêmica (como tenta fazer o Executivo Federal brasileiro) - é importante enfatizarmos aqui que o Estado soberano brasileiro está atuando praticamente de modo dividido em suas diversas instâncias, como será tratado adiante.

O Estado é a instância institucional central e inescapável que (a) formula leis e políticas para lidar com as dimensões da crise; (b) arrecada impostos e planejará os gastos públicos para lidar com elas, emitirá moeda, se necessário; (c) altera leis e restringe direitos civis, políticos e econômicos para implementar a obrigatoriedade do isolamento físico; (d) altera leis, formula e implementa políticas para organizar e financiar políticas de saúde pública para conter o alastramento de mortes pela Covid-19; (e) altera leis, formula e implementa políticas para assegurar algum grau de direito à subsistência em economias profundamente afetadas pelo isolamento social que paralisa diversas atividades produtivas e de mercado; $\mathrm{e}(\mathrm{f})$ exercita o monopólio da violência legítima para obrigar a cooperação social em torno de todas as políticas agora mencionadas. Ou, em pior cenário, é o Estado que inviabiliza as ações de (a) a (f), expressando a ideia de que a pandemia não deve ser contida por mecanismos coletivos próprios da soberania estatal, mas por meio de ações descentralizadas e independentes de atores individuais e coletivos privados, próprio das interações de mercado e das interações entre cidadãos no exercício de suas liberdades civis. Felizmente, esse pior cenário não se verifica plenamente em nosso país, ora com o Executivo central ocupado por grupos políticos que negam a pandemia, 
por resistência do Legislativo e, em parte, do Judiciário, como de resto foi mostrado neste livro.

Decorre do exposto no parágrafo acima que a pandemia é teorizável como estatal não só pela ação estatal sobre o caráter social da pandemia, mas também porque é essa ação estatal soberana que estrutura o impacto da pandemia sobre as vidas individuais e comunitárias. $\mathrm{O}$ alastramento da doença e das mortes, o aumento ou não da fome e da miséria, o aumento ou não da desigualdade econômica, a efetivação ou não do isolamento físico, a implementação ou não de políticas de enfrentamento da pandemia que respeitem ou desrespeitem direitos civis, políticos, socioeconômicos e de segurança dependerão da ação e caminhos estatais.

Isso não significa que a pandemia seja apenas estatal ou predominantemente estatal, afinal, como argumentamos acima, a pandemia é social no sentido específico de que as dimensões sociais da pandemia são analiticamente distinguíveis, mas empiricamente indissociáveis. Mas, nossa segunda consideração afirmava que a pandemia é estatal e que a pandemia é política. Por que, teoricamente, distinguimos estatal de político?

Basilarmente, porque política não inclui apenas instituições estatais e atores estatais. Muitos dos atores da política pertencem ao âmbito da sociedade civil e, caso utilizemos um conceito de sociedade civil que exclua o mercado, atores econômicos. E é central, para o entendimento da política e do próprio Estado, o olhar direcionado tanto para a operação propriamente estatal quanto para as diversas forças societais que fazem parte dos movimentos $\mathrm{da}$ política em torno da ocupação do Estado, da disputa pelo Estado, da responsividade estatal à opinião pública, da repressão política, da liberdade política, da permeabilidade entre Estado e sociedade civil. As interaçôes entre as instituições estatais enquanto arenas políticas, as instituições estatais enquanto atores políticos, as instituições e associações civis não estatais politizadas, os partidos e o eleitorado fazem parte do que conforma o próprio Estado e as políticas estatais. 
E essa conformação pode ser mais ou menos democrática, ou mais ou menos autocrática. Os movimentos democratizantes e autocratizantes da política são importantes sempre e guardam peculiaridades especialmente cruciais quando as sociedades enfrentam crises sociais agudas como a pandemia de Covid-19.

Assim, de acordo com a formulação apresentada aqui, a pandemia é teorizável como política porque diz respeito ao Estado em conjunto com as forças políticas e movimentos da política que incluem, mas também transcendem, as fronteiras analíticas do que éo Estado enquanto arena política e do que é o Estado enquanto ator (e atores, já que o Estado soberano é encarnado por muitas instituições estatais) político em sociedade.

\section{A não interrupção da democracia}

Como vimos nas seções iniciais do capítulo de Feres Jr., as crises de grande monta e profundidade, historicamente, foram construídas como questão social a ser politicamente resolvida de modo autocrático. Neste modo autocrático, foram incluídas as ditaduras (comissárias ou não), as monarquias, mas também os estados de exceção institucionalizados como Estado de Defesa e Estado de Sítio. O que reúne essas formas políticas, dentro do sentido conceitual necessário ao argumento presente no capítulo 7, é que elas, normativamente, expressam a ideia de que o Estado e o governo agem legitimamente mesmo quando o povo é forçado a abdicar de seu papel de titular moral da soberania no sentido ideológico fundamental de democracia, como governo do povo, pelo povo e para o povo. O governo autocrático e o momento autocrático são aqueles em que o povo é, ideologicamente, não uma comunidade de cidadãos politicamente iguais (mesmo que apenas formalmente), mas uma comunidade de súditos do governo e do Estado.

$\mathrm{Na}$ solução autocrática das crises está expressa visão política segundo a qual há problemas cuja gravidade assume tal feição, mag- 
nitude e urgência que sua solução não pode ser pensada e decidida responsivamente à opinião pública e a um corpo de cidadãos livres e iguais, pois os cidadãos, coletiva e dialogicamente, não seriam capazes de pensar e discutir o problema e nem mesmo representantes políticos eleitos teriam essa capacidade.

Se pensamos os seres humanos como iguais em dignidade, liberdade e capacidade moral frente ao bem e à justiça, somos normativamente contrários ao paternalismo e apenas contextos de crise justificam ou justificariam momentos autocráticos. Afinal, é a feição, magnitude e urgência de um mal e de um perigo que torna a interação entre agentes individuais iguais morosa e falha na construção da solução política e estatal. Em condições que não são críticas, apenas a democracia é justificável e as instituições estatais devem ser tais que encarnem os valores da igualdade e da liberdade políticas. A democracia expressa a compatibilização entre autodeterminação individual e coletiva dos cidadãos. É claro que essa compatibilização tem conteúdos substantivos muito diversos em concepções teóricas distintas do que é democracia - lembremos que, no mínimo, temos três grandes vertentes de teoria e ideologia democrática: a eleitoral representativa, a participativa e a deliberativa.

Quando foi decretado o estado de emergência resultante da pandemia, as medidas de isolamento físico impediram o funcionamento regular presencial do Congresso, o governo federal insinuou a possibilidade da decretação do Estado de Sítio e o Congresso, agilmente, preparou a institucionalidade do Sistema de Deliberação Remota (por meio de burocracia, legislação e interpretação de leis). Isso permitiu que, com delimitação de seus modos de procedimento e escopo, a questão política de como lidar com a pandemia fosse discutida, formulada e implementada com o máximo possível de normalidade democrática.

E, um pouco mais especificamente dentro das muitas articulações entre instituições estatais democráticas, foi construído politicamente que as muitas políticas formuladas em tempos pandêmicos, 
com suas vastas consequências sobre os direitos dos cidadãos brasileiros, não deveriam perder o lastro normativo da representatividade específica do Poder Legislativo federal. A representação política democrática, como bem coloca Robert Post (2014), é profundamente ancorada no vínculo eleitoral e na construção de vinculações entre as ações dos políticos eleitos e a opinião pública expressa por seus eleitores. O Congresso brasileiro possui representantes eleitos que, na combinação do tipo de constituency do Senado e da Câmara dos Deputados Federais, constrói vínculos de representação democrática conectados a um rol mais plural de interesses, não apenas estaduais, mas também de grupos dentro dos estados que se diluem excessivamente no majoritarismo da eleição presidencial.

É extremamente simbólico que o Legislativo, poder representativamente democrático por excelência e coração da moralidade democrática, tenha sido motor da preservação da normalidade institucional possível. Bem como é extremamente simbólico que isso tenha acontecido em um momento em que é tão forte a percepção de que o Brasil vive uma crise de sua democracia e de que "as instituições não estão funcionando". Sejam quais forem as explicações científicas possíveis dessa construção da pandemia como crise a se solucionar democraticamente, este simbolismo carrega potencialidades normativas e políticas positivas para aqueles que endossam o credo democrático e o credo no Estado de Direito, ambos antitéticos frente ao Estado de Sítio.

Não sabemos como isso será traduzido e cultivado em nossa cultura política pública, mas o fato é que o Congresso brasileiro, em tempo célere, reagiu a uma crise profunda e de magnitude global, construindo-a politicamente como compatível com a democracia. Não sabemos como Judiciário e Executivo teriam agido sem essa atuação democrática do Legislativo. Mas sabemos que um modo democrático de se lidar estatal e politicamente com crises agudas está em construção. Resta às forças democráticas e liberais de nosso país que consigam fazer com que esse modo não naufrague. 
Também não sabemos ainda quais os resultados efetivos das políticas mais ou menos democraticamente formuladas para o enfrentamento da pandemia, mas já sabemos que o Congresso tem sido, mesmo em funcionamento remoto, terreno fundamental para que o Executivo Federal não ignore as muitas faces econômicas e médico-sanitárias da crise pandêmica. De maneiras a serem cientificamente investigadas, o Congresso tem funcionado, dentro do sistema de pesos e contrapesos do Estado brasileiro, como um dos freios democratizantes frente a tentativas de fortalecimento autocrático. Novamente, estamos apenas no campo da exploração de potencialidades políticas positivas do significado normativo e ideológico do fato do Congresso Remoto ter se tornado uma realidade.

Por fim, por mais que possa parecer contraintuitivo, a continuidade do funcionamento do Congresso permitiu que a questão da pandemia não fosse despolitizada, isto é, reduzida a um problema autocraticamente administrado, e que os direitos de fato golpeados pela pandemia da Covid-19 o fossem de modo democrático, e não pela intervenção de um Estado de Sítio. A solução do Congresso Remoto foi produto da pluralidade de forças políticas da sociedade brasileira, cujos conflitos permitiram a ascensão do atual governo, mas que são complexas e diversificadas demais para endossarem plenamente suas aventuras antidemocráticas.

\section{Referências}

Lévy, Bernard-Henri. The Virus in the Age of Madness. New Haven: Yale University Press, 2020.

Post, Robert. Citizens divided: campaign finance reform and the Constitution. Cambridge: Harvard University Press, 2014. 